\title{
Public-Private Partnerships to Address Global Environmental Problem: Sino-US Cooperation on Climate Change and Energy
}

\author{
Fang-Ting CHENG \\ Institution of Developing Economies, JETRO, Chiba-shi, Chiba, Japan
}

\begin{abstract}
The study indicates that public-private partnerships (PPPs) can play "strategic", "practical", or "regulative" roles by making use of "instrumental", "institutional", and "normative" approaches in tackling political issues between countries. PPPs have often been discussed in studies of urban development, service provision, health care, and so on, but they have rarely been analyzed in terms of international relations and political problems on global environmental issues. This study takes an environmental problem-Sino-US energy and climate change cooperation - as a case study to inspect the possible roles and approaches of PPPs. Sino-US cooperation has been launched such as under the Strategic \& Economic Dialogue (S\&ED) by both administrations, which has significantly contributed to their reconciliation of domestic abatement policies in climate change, environmental protection, and energy. The establishment of schemes such as the Ten-Year Framework for Cooperation on Energy and Environment (TYF), the EcoPartnerships, and wide-ranging dialogues and initiatives on clean energy and clean vehicles, in which both public and private actors participate, are among the important approaches of facilitating bilateral cooperation. The study concludes that these schemes have played strategic and practical roles in strengthening the degree of mutual trust and in facilitating the progress of cooperation, although more investigations are needed to considerate their regulative roles. The application of instrumental, institutional, and normative approaches have been observed through the implementation of the TYF and EcoPartnerships.
\end{abstract}

Keywords: Public-Private Partnerships (PPPs), Sino-US relations, Strategic \& Economic Dialogue (S\&ED), Eco-Partnerships, energy efficiency, and climate change, public-private partnerships (ppps), S\&ED, climate change, sino-us relations, energy efficiency

\section{Introduction}

Public-private partnerships (PPPs) have been indicated as a new type of tool for transnational governance that can increase problem-solving capacity, that is, cost effectiveness and democratic accountability, which can be regarded as legitimacy (Börzel \& Risse, 2005, p. 195; Klitgaard, 2011; Kouwenhoven, 1993; Porter, 2005, p. 222). Börzel and Risse argued that both public and non-state (here we use private) actors can both be involved in governance under a non-hierarchical structure. Non-hierarchical governance, according to Börzel and Risse, can be formed and sustain itself by boosting positive incentives, bargaining, arguing, and non-manipulative persuasion among actors. Thus, compared with hierarchical governance, private actors are better able to delegate public functions, to establish networks and partnerships, or to behave under corporatism. Private actors also introduce norms and problem-solving approaches to international affairs, such as "benchmarking", "race to

Fang-Ting CHENG, Institution of Developing Economies, JETRO. 
the top", "risk management", and so on (Fraser, 2002; Porter, 2005, p. 220; Rabe, 2006; Tews, Busch, \& Jörgens, 2003; Wynne, 1992; Yale University and Columbia University, 2005). Private actors may include the for-profit sector (i.e., companies, firms, interest groups) as well as the non-profit sector (i.e., non-governmental organizations and academic institutions) (Börzel \& Risse, 2005, p. 197).

However, not much attention has been paid to PPPs in previous studies on certain internationally highly politicalized issues, even though these are largely demanding of both public and private sectors' involvement. Unlike trade, health care, resource, finance, or development issues, governance on problems of environmental destruction, such as loss of biodiversity, deforestation, trans-border air pollution, waste, and progressive climate change, etc., are often entwined with the opposition between different national interests, in contrast, while demanding a significant degree of participation of private sectors, on the other hand (Berkley, 2006; Klitgaard, 2011; Stevenson, 2014; Streck \& Lee, 2016). In these cases, even when public-private corporations exist and progress at considerable levels, the roles and effectiveness are easily underestimated because nation-affiliated confrontation does not always completely ease in the short term. This is the reason why studies on public-private relationships and their implications for global environmental governance are still few compared with other fields of research.

Research on PPPs traditionally focuses on cooperation in or between developed countries, such as the United States, Germany, Sweden, the UK, Norway, and Canada, by means of studies on the service industry, business community, local economics, urban development, and, recently, emergency management (Beauregard, 1998; Carter, 2008; Dewulf, Blanken, \& Bult-Spiering, 2012; Hodge \& Greve, 2007; Savas, 2000; Siemiatycki, 2006; Walzer \& Jacobs, 1998; Westeren, 2000). However, there is an obvious lack of theoretical perspectives to analyze the cooperation between public and private actors in both developed and developing countries. Especially the fact that developing countries demand knowledge capacity, human resources, technologies, and financial investment to solve urgent problems, whereas developed countries search for emerging markets, provides strong incentives for both sides to establish cooperative relationships. The huge markets in developing countries and their cooperative behavior are of interest to developed countries, owing to their highly sophisticated capabilities, in order to stay influential on these specific issues. This is why numerous projects have been implemented in studies on energy-saving, environmental protection, and climate change in recent years (Streck \& Lee, 2016).

Based on the above, there is a lack of attention on important global issues (e.g., energy and environment, climate change, etc.) and a lack of analyses of the cooperation between developed and developing countries in PPPs research. Therefore, the study aims to understand the roles and approaches of public and private partnerships on both sides and to specify how these possibly influence the behavior between confronting states regarding controversially politicalized topics. The combating of climate change and corresponding energy policies in the US and China, within the framework of the US-China Strategic and Economic Dialogue (SED, later S\&ED) and its Ten-Year Framework (TYF) and EcoPartnerships, was chosen as a case study for this study.

After the end of the Cold War, climate change and its international negotiations were raised as one of the most important topics in international relations, although it is not a highly hierarchical issue compared with military security or arms control. Not surprisingly, owing to the disagreement on the abatement of responsibility among developed and developing countries, the global policy-making process progressed at a very slow pace. Nonetheless, the confrontation between the major players, especially the US and China, which 
were considered as lagging behind in terms of international cooperation, has shifted their actions and policies toward a relatively harmonic manner in recent years. How did the US and China achieve their common goals on climate change? To answer this, it is necessary to clarify what kinds of approaches were used in facilitating their cooperation. Moreover, another question that needs to be answered is whetheror not those approaches, such as numerous public-private partnership projects, have substantially contributed to reciprocal relations.

To clarify, the purpose of this study is not to argue about public and private cooperation but rather to investigate why and how public-private partnerships are formed among confronting states and how these partnerships possibly affect international relations between developed and developing countries regarding specific controversial issues. This study focuses on cooperation on energy policy and climate change between the US and China.

The study is structured as follows: The first section presents the analytical framework, based on previous studies, to identify the roles and approaches of PPPs in terms of international cooperation. In the second part, the case of Sino-US cooperation on energy, environment, and climate change will be investigated. The final sections, followed by a summary and conclusions, examine whether the analytical framework correctly explains the US-China case.

\section{PPPs Between States to Tackle Global Issues}

As for the definition, the UK and Canadian governments present PPPs as "the arrangements between government and private sector entities for the purpose of providing public infrastructure, community facilities and related services. Such partnerships are characterized by the sharing of investment, risk, responsibility and reward between the partners" (Schaeffer \& Loveridge, 2002, p. 170). However, there is a need to reconsider the understanding of PPPs when we apply the concept to cooperation between actors in developed and developing countries. In such a case, the partnerships may strongly embrace political purposes inorder to enhance conversations and mitigate existing mutual distrust.

According to Andonova, PPPs can be defined as agreements for collaborative governance between public actors and non-state actors, which establish common norms, rules, objectives, and decision-making and implementation procedures for a set of policy problems (Andonova, 2010, pp. 25-26). Andonova studies global PPPs at international arena by using principal-agent model. The focused PPPs are mostly within international organizations (IOs) or between IOs and national states (Andonova, 2010). In addition, Stevenson reviews three books on natural resources extraction from the perspective of PPPs. These books are common in telling the story of pursuing both state power and corporate profit in the same time by establishing collaboration between public and private sectors (Stevenson, 2014).

On the other hand, Linder and Rosenau defined PPPs as "the formation of cooperative relationships between government, profit-making (for-profit) firms, and non-profit private organizations to fulfill a policy function" (Linder \& Rosenau, 2000, p. 5). Börzel and Risse mentioned non-state actors can include for-profit organizations, such as corporations and interest groups, whereas the non-profit sector can include public interest groups, NGOs/NPOs, voluntary organizations, or advocacy networks, etc. (Börzel \& Risse, 2005).

Andonava, Linder and Rosenau, and Börzel and Risse's interpretation towards PPPs are considered fair from the perspective of interpretability, that is, the forms, actors, and purposes can be polyphyletic. Particularly, 
Börzel and Risse provided a framework for the context of PPPs in transnational governance according to the levels of autonomy of actors (Börzel \& Risse, 2005). Although it is useful for analyzing transnational governance that involves both public and private actors in the negotiation and decision-making process, it does not sufficiently explain the PPPs that have recently been established and are in their initial stages to serve some specific purposes before they can participate in international negotiations. For some partnerships, let alone governance, it is possible to say that mere efforts, such as searching common ground or knowledge sharing, can be considered main objectives between transnational actors. Therefore, different from previous studies, this paper aims to analyze PPPs between private actors and national states under each jurisdiction on global environmental issue, especially those problems under debate, by answering why and how the partnerships have been established, as well as to observe possible influence brought by these efforts. The next section argues that the roles and approaches of PPPs can have implications for public-private cooperation in their early stages regarding politically and economically complicated problems between states with conflicting values and interests.

\section{The Roles and Approaches of PPPs}

Börzel and Risse (2005) indicated that transnational PPPs would be "institutionalized cooperative relationships between public actors, both governments and international organizations, and private actors beyond the nation-state for governance purposes". Governance purposes, by their definition, refer to "the making and implementation of norms and rules for the provision of goods and services that are considered as binding by members of the international community". Thus, these governance purposes can contain explicit norms, rules, and decision-making procedures, and may also include informal governance arrangements.

The above role and purpose of PPPs may apply to states with more stable relations, which have mutual trust in each other, and possess basic common values on specific issues. However, it is considered difficult to explain partnerships that are established to solve complicated issues entangled with conflicting political interests (i.e., global environmental problems involve both developed and developing countries). Meanwhile, the attempt to limit the purpose of partnerships to the negotiation or implementation of rules and norms could diminish the usability of an analytical perspective. Therefore, this study's additional objective is to provide an analytical framework that can explain the roles and approaches of PPPs from their initiation to the implementation of norms and rules as well as the provision of goods and services for meeting governance needs.

To understand the nature of partnerships, previous studies have considered the importance of their "open-ended" characteristic, which implies broader purposes and their occasional "policy-strategy-making collaboration" characteristic (Kleinberger, 1995; McGuire, 2000; Peters, 1998; Rosenau, 2000; Schaeffer \& Loveridge, 2002; Steffen, 1997). This study also considers that PPPs' purposes can be expressed in a dynamic and comprehensive manner, as long as the relationship is continuous, enduring, and authentic; that is, a close collaboration and the combined strengths of private and public sectors sustain it (Peters, 1998; Rosenau, 2000).

Based on the above premise, this study argues that the roles of PPPs can range between strategic, practical, and regulative, differing from issue to issue. The approaches of PPPs are instrumental, institutional, and normative. These two variables classify PPPs into nine types of cooperation (see Table 1).

Surely, PPPs are put into practice according to actors' own benefits and intentions. To solve problems of recognition and inadequate mutual trust, strategic roles, especially based on partners' political purposes, are 
considered necessary to build confidence, such as shared vision, understanding, and common ground between actors to achieve reciprocal relations (McGuire, 2000, pp. 281-282). Subsequently, based on a certain degree of mutual trust, practices that include knowledge sharing, capacity building, and benchmarking are considered to constitute another practical role (Börzel \& Risse 2005; Haas, 1989; Jasanoff, 2004; Tews, Buschand, \& Jörgens, 2003; Yale University and Columbia University, 2005). When partnerships search for common rules and standards, actors will start to negotiate with each other regarding their regulative roles, as has been shown by many prior researches (Andonova 2010; Börzel \& Risse 2005; Schaeffer \& Loveridge, 2002; Stevenson, 2014).

Table 1

Transition From Traditional to Social Web Marketing

\begin{tabular}{|c|c|c|}
\hline Components & Traditional Marketing & New Way of Marketing \\
\hline $\begin{array}{l}\text { Marketing } \\
\text { understanding }\end{array}$ & $\begin{array}{l}\text { One-way, one-sided communication that explains the } \\
\text { brand. }\end{array}$ & $\begin{array}{l}\text { To nurture relationships and dialogues, to be more } \\
\text { transparent, to gain confidence, to create credibility. }\end{array}$ \\
\hline Brand value & It is important to remind the brand. & $\begin{array}{l}\text { Brand value is determined by the customer: When } \\
\text { does the customer recommend the goods or service? }\end{array}$ \\
\hline Segmentation & Customer groups according to demographics. & $\begin{array}{l}\text { Customer groups by interest, attitude, behavior: What } \\
\text { is important for customers? }\end{array}$ \\
\hline Targeting & $\begin{array}{l}\text { Targeting by demographics, especially media } \\
\text { purchases. }\end{array}$ & Targeting by customer behavior. \\
\hline Communication & $\begin{array}{l}\text { Radio-television broadcasting style: The message } \\
\text { transmitted and created forcibly for the client's } \\
\text { assimilation. }\end{array}$ & $\begin{array}{l}\text { Dialogue, personal opinion, customer comments, or } \\
\text { digital environment for interactive communication } \\
\text { through search and examination. }\end{array}$ \\
\hline Content & $\begin{array}{l}\text { Professional content created and controlled by } \\
\text { marketers. }\end{array}$ & $\begin{array}{l}\text { Increasingly professional and user-created mixed } \\
\text { content. }\end{array}$ \\
\hline Viralization & $\begin{array}{l}\text { The popularity driven by striking presentation rather } \\
\text { than the content }\end{array}$ & $\begin{array}{l}\text { Viralization is based on reliable content about } \\
\text { remarkable products or features that enable people to } \\
\text { talk and send emails. }\end{array}$ \\
\hline Views & Experts contribute strongly to the debate. & Users can view and rate everything. \\
\hline $\begin{array}{l}\text { Role of publisher } \\
\text { and advertiser }\end{array}$ & $\begin{array}{l}\text { The publisher establishes channels and control the } \\
\text { content that will collect viewers for advertisers who } \\
\text { sponsor channels or programs. }\end{array}$ & $\begin{array}{l}\text { Establishing relationships through sponsorship of the } \\
\text { content and interacting with customers where, how, } \\
\text { and when they want }\end{array}$ \\
\hline Strategy & $\begin{array}{l}\text { Top to bottom strategy, which is applied by the top } \\
\text { management, determine the tactics. }\end{array}$ & $\begin{array}{l}\text { Top to bottom strategy develops successful ideas } \\
\text { gathered from continuous testing and customer input. }\end{array}$ \\
\hline Hierarchy & $\begin{array}{l}\text { The information is organized into channelsfor } \\
\text { eligible advertisers, files and categories. }\end{array}$ & $\begin{array}{l}\text { Information can be obtained with the desired } \\
\text { keyword for the appropriate users. }\end{array}$ \\
\hline Payment & $\begin{array}{l}\text { Cost per thousand / mille with an advertising } \\
\text { campaign (CPM): Cost is emphasized. Advertisers } \\
\text { buy ideas (Share of Voice = Mind share = Market } \\
\text { share) }\end{array}$ & $\begin{array}{l}\text { Return on investment (ROI): It is investing in } \\
\text { marketing for future growth. Profitability is based on } \\
\text { measurable returns. }\end{array}$ \\
\hline
\end{tabular}

Note. Resource: Akar, 2010, pp. 31-32.

In order to achieve these above-mentioned roles, three approaches, namely, instrumental, institutional, and normative, must be considered possible and necessary. The purpose of the instrumental approach is to strengthen the sharing of information and knowledge as well as to promote learning processes through specific forums/dialogues and platforms or data exchanges (Börzel \& Risse 2005). Furthermore, the institutional approach aims to specify or even introduce policies and rules for each partner, respectively. Through regular/irregular communication and interaction, partners will be able to enhance their problem-solving abilities and thus implement tangible rules or regulations. Third, the normative approach means to co-facilitate over or further negotiate common norms, rules, procedures, or even regulations. The institutional approach 
focuses on rule-making, in respective part, whereas the normative approach moves toward collective actions. However, these approaches vary in regard to different actions and behavior according to the roles of partnerships.

In terms of its strategic role, the instrumental approach includes political dialogue, conversation, and network-building between or among public and private actors in order to enhance mutual trust and build confidence. These efforts can be institutionalized through regular or irregular dialogues and meetings to further reach actors' strategic and reciprocal purposes. Strategic-institutional patterns, although they are not necessary to relate to international negotiations, indicate that private actors engage in consultation and are part of delegations. Institutionalized opinion exchanges in periodic meetings would benefit problem-shooting or, for instance, agenda-setting, to bring about further intentions of deepening cooperation. The normative approach with strategic purpose would produce political agreement, such as joint statements and communiqués over fundamental principles.

Secondly, the practical roles of distinct approaches represent the different characteristics of PPPs. The practical-instrumental pattern looks for shared knowledge, best practices, and benchmarks. It helps partners to exchange resources and identify top runners in solving problems, and furthermore provides actors with intentions to imitate and start learning processes. Actions and behavior according to the practical-institutional pattern include platforms of expertise provision, capacity building, resource management, training, and so on. The normative approach looks for possibilities to accelerate partnerships by clarifying cooperative agendas and items in mutually agreed forms, such as the Memorandum of Understanding (MOU), action plans, standards of conduct, etc.

Lastly, partnerships that exert regulative roles search for rules/standards-settings and co-regulation. Through the instrumental approach, partners can investigate possible regulative rules or policy options via experience sharing. For this purpose, the institutional approach can range from research and introduction to the implementation of regulation for each actor's part. Private actors in particular delegate partial functions of the public sector when they forge feasible rules. The strongest partnership can be understood as part of a regulative-normative pattern, in which public and private actors participate as stakeholders in negotiating bilateral/multilateral agreements (Börzel \& Risse, 2005). This pattern gradually features a strengthened status of non-state actors in the joint rule-making process and in the implementation of cross-border regulations.

\section{The Sino-US Strategic Partnership on Energy and Climate Change}

Notwithstanding the US and China's disagreement over the responsibility for tackling climate change, which was identified as the main cause of the stalemate in their negotiations, the two countries have recently agreed to cooperate on reducing or slowing the increase of GHG emissions (Han et al., 2009; International Energy Agency, 2015). Sino-US cooperation on climate change has expanded and intensified to a great extentin recent years (Author, 2015). To better understand the bilateral partnerships on climate change, energy, and environment in each country, the development of bilateral cooperation will be discussed below by reviewing the frameworks and projects that have been implemented in recent years.

\section{Sino-USSED (2006-2008) and S\&ED (2009-Current)}

The US-China Strategic Economic Dialogue (SED) was established to facilitate the discussion on topics related to US and Chinese economic issues under the G.W. Bush and Hu Jintao administrations in 2006. SED 
was held five times in total with periodic meetings from 2006 to 2008, and it has continued as the US-China Strategic and Economic Dialogue (S\&ED) under the Barack Obama administration since 2009 (US Department of State, 2011). SED was initiated by the US Department of Treasury, spearheaded by its former Secretary Henry Paulson, who had been advocating closer economic relations with China, including environmental protection and sustainable economic growth. SED later expanded its focus to embrace a wider range of topics, and as a result the current US State Department was given a broader authority by the Obama administration. ${ }^{1}$

To deal with energy and environmental issues, the Ten-Year Framework for Cooperation on Energy and Environment (TYF) was established in 2008 at the 4th SED. The TYF aims to foster innovative solutions for existing energy and environmental problems by facilitating the exchange of information and best practices (US Department of State, 2012). So far, there have been seven focus areas for the TYF, participated in by various sub-national public and private actors from the US and China in order to encourage innovation and sustainable development among state and non-state stakeholders. Further details on the TYF are provided in the next section.

Since 2009, China and the US have been holding periodic S\&ED to discuss the critical issues between them. At the first S\&ED, held in July 2009, the US and China signed the Memorandum of Understanding to Enhance Cooperation on Climate Change, Energy and the Environment (MOU), which can be considered as a startup for cooperation on energy and climate change. The 2009 MOU aimed at cooperation on a wide range of issues, while strengthening the existing TYF (see Figure 1 and Table 2).

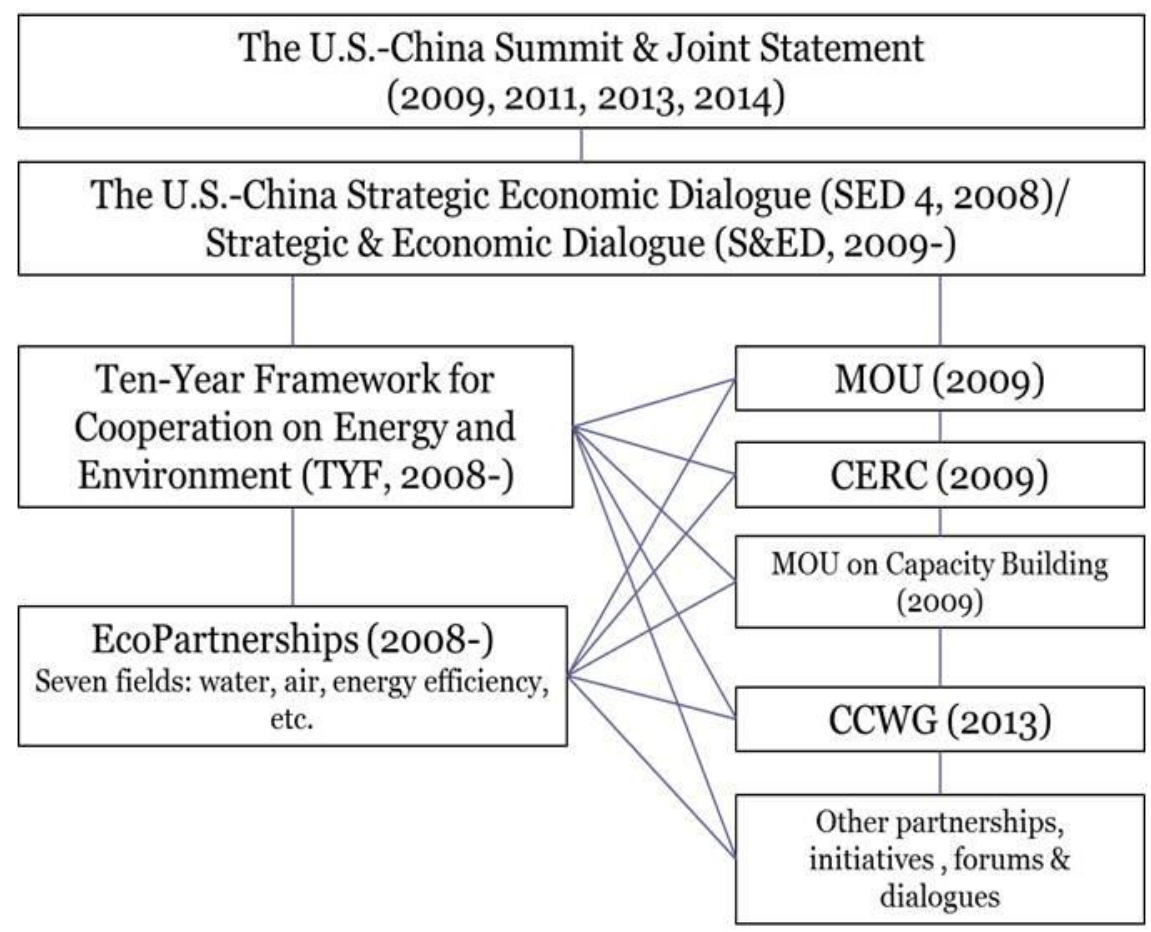

Figure 1. Structure of Sino-US Partnerships on Energy and Climate Change (Lines refer to the linkages between the arrangements; Source: Author).

\footnotetext{
${ }^{1}$ Interview with a research fellow at the Center for Strategic and International Studies (CSIS), November 14, 2014, Washington, D.C.
} 
Table 2

Sino-US Cooperation on Energy and Climate Change

\begin{tabular}{|c|c|c|}
\hline $\begin{array}{l}\text { Year/ } \\
\text { Month }\end{array}$ & Cooperation & Cooperation Topics/Focuses Areas \\
\hline 2008. 6 & $\begin{array}{l}\text { SED } 4 \\
\text { Initiating TYF and EcoPartnerships }\end{array}$ & $\begin{array}{l}\text { (1) Energy saving of electric power systems and logistics } \\
\text { (2) Efficiency of transportation } \\
\text { (3) Water pollution } \\
\text { (4) Air pollution } \\
\text { (5) Forests and wetlands protection }\end{array}$ \\
\hline 2009.7 & $\begin{array}{l}\text { S\&ED I } \\
\text { Joint Press Statement of the First } \\
\text { S\&ED }\end{array}$ & Signature of First Memorandum on climate change \\
\hline 2009.7 & $\begin{array}{l}\text { S\&ED I } \\
\text { Memorandum of Understanding to } \\
\text { Enhance Cooperation on Climate } \\
\text { Change, Energy and the Environment }\end{array}$ & $\begin{array}{l}10 \text { fields in a cooperative relationship including: } \\
\text { Energy-saving } \\
\text { Renewable energy } \\
\text { Clean coal } \\
\text { Carbon Capture and Storage (CCS) }\end{array}$ \\
\hline 2009. 11 & $\begin{array}{l}\text { The Sino-US Joint Statement } \\
\text { (President Obama visits China) }\end{array}$ & $\begin{array}{l}\text { To launch or to establish: } \\
\text { (1) The clean energy research center } \\
\text { (2) The Electric Vehicles Initiative } \\
\text { (3) New energy saving action plan } \\
\text { (4) New renewable energy partnership } \\
\text { (5) Large scale CCS project } \\
\text { (6) Promotion of clean coal } \\
\text { (7) New Shale Gas Initiative } \\
\text { (8) The Energy Cooperation Program (ECP) }\end{array}$ \\
\hline 2009.11 & $\begin{array}{l}\text { Protocol for Cooperation on a Clean } \\
\text { Energy Research Center }\end{array}$ & $\begin{array}{l}\text { Research subjects include: } \\
\text { Energy efficiency of buildings } \\
\text { Clean energy } \\
\text { CCS } \\
\text { Clean vehicles } \\
\text { To support: } \\
\text { (1) The Electric Vehicles Initiative } \\
\text { (2) Large scale CCS project }\end{array}$ \\
\hline 2011.1 & $\begin{array}{l}\text { The Sino-US Joint Statement } \\
\text { (President Hu visits the US) }\end{array}$ & $\begin{array}{l}\text { Confirmation of current dialogues and negotiations. } \\
\text { Support for UNFCCC, COP and the Cancun Agreement }\end{array}$ \\
\hline 2011.5 & $\begin{array}{l}\text { S\&ED III } \\
\text { Improvement of TYF and } \\
\text { EcoPartnerships }\end{array}$ & Signature of the six new eco-partnerships under the TYF. \\
\hline 2013.4 & $\begin{array}{l}\text { Joint Sino-US Statement on Climate } \\
\text { Change }\end{array}$ & $\begin{array}{l}\text { Establishment of the Sino-US Bilateral Working Group on Climate Change } \\
\text { (CCWG) }\end{array}$ \\
\hline 2013.6 & $\begin{array}{l}\text { The Sino-US Joint Statement } \\
\text { (President Xi visits the US) }\end{array}$ & $\begin{array}{l}\text { Phase down the consumption and production of hydro fluorocarbons (HFCs) } \\
\text { under the Montreal Protocol }\end{array}$ \\
\hline 2013.7 & $\begin{array}{l}\text { S\&ED V } \\
\text { The Sino-US Joint Statement }\end{array}$ & $\begin{array}{l}\text { Continuation of the current work of the CCWG } \\
5 \text { fields of cooperation were added to prompt GHG emission reduction }\end{array}$ \\
\hline 2014.7 & S\&ED VI & $\begin{array}{l}\text { New } 8 \text { EcoPartnerships } \\
\text { CCWG special event on the private sector } \\
\text { Policy dialogue among top negotiators }\end{array}$ \\
\hline 2014.11 & $\begin{array}{l}\text { APEC Summit (Beijing) } \\
\text { Sino-US Joint Announcement on } \\
\text { Climate Change and Clean Energy } \\
\text { Cooperation }\end{array}$ & $\begin{array}{l}\text { Reduction of } 26 \% \text { 28\% GHG emissions by } 2025 \text { from } 2005 \text { levels in the US } \\
\text { CO2 emissions peak out around } 2030 \text { in China; Increase of the non-fossil fuel } \\
\text { share of all energy upto around } 20 \% \text { by } 2030\end{array}$ \\
\hline 2015.6 & S\&ED VII & $\begin{array}{l}\text { Two high-level events to strengthen joint efforts on climate change: a public } \\
\text { dialogue, and a private joint session on climate change } \\
\text { Announcement of newprojects, initiative, programs and EcoPartnerships } \\
\text { Discussion on } 2015 \text { Paris agreement through an "enhanced policy dialogue" }\end{array}$ \\
\hline
\end{tabular}

Notes. Source: Author; References: US State Department; Committee on Sino-US Cooperation on Electricity from Renewable Resources et al 2010, 205-216; Sino-US EcoPartnership official website. 
In the MOU, the US and China agree to launch a new action plan for energy efficiency under the TYF. Furthermore, in order to achieve mutual goals, the Memorandum of Capacity Building ${ }^{2}$ and the Protocol Clean Energy Research Center (CERC) ${ }^{3}$ were also signed (see Figure 1). In the latter document, China and the US agreed to finance the CERC with a minimum of US $\$ 150$ million each before 2015 , in order to provide the means for facilitate interactions between engineers and researchers from both sides. The main research topics of the CERC that will be given precedence include (1) energy-efficient buildings, (2) clean energy (including CCS), (3) clean vehicles, and (4) clean coal technology. In particular, they agreed to introduce large-scale CCS projects to facilitate quick action on technical development and the use, spread, and transfer of technologies. Moreover, the two countries agreed to cooperate by establishing the Climate Change Policy Dialogue to facilitate policy cooperation on climate change.

At the second S\&ED in May 2010, they decided to deal with energy and climate change-related issues by announcing an action plan under the S\&ED and TYF, and they signed an Implementation Plan for EcoPartnerships. During the second S\&ED, both sides agreed to hold (1) the first US and China Energy Efficiency Forum, (2) the Electric Vehicles Forum, (3) the first Renewable Energy Forum, (4) an Energy Policy Dialogue, (5) the Oil and Gas Industry Forum, and (6) to run the Clean Energy Research Center Working Group as well as the Renewable Energy Partnership. These partnerships aim to promote collaborative relationships between the public and private sectors. In addition, the dialogue was designed to accelerate the application of clean energy by improving technologies and companies' competitiveness.

The subject of climate change was again taken up in a Joint Statement at the Sino-US Summit in January 2011, when Chinese President Hu Jintao visited the US both sides agreed to support the Clean Energy Research Center, the Renewable Energy Partnership, the Joint Statement of Cooperation on Energy Security, the TYF, and the Cancun Agreement (US Department of State 2011; the Cancun Agreement). At the same time, they agreed to continue to negotiate under the United Nations Framework Convention on Climate Change (UNFCCC). Sometime later, energy security, climate change, and environmental protection were again central topics at the 3rd S\&ED. At this meeting, the US and China further expanded their cooperation by signing six new EcoPartnerships under the TYF. Their EcoPartnerships currently contains seven focus areas, including clean air, clean water, and energy efficiency, etc.

In 2013, the Bilateral Sino-US Working Group on Climate Change (CCWG) was set up and became one of the most important focus points of the strategic partnerships (US Department of State, 2013a). The two sides agreed on a joint effort to phase-out the emission and consumption of Hydro fluorocarbons (HFCs) (US Department of State, 2013b). This is the first time that the US and China cooperated on GHG emission reduction, and both confirmed that they would continue their efforts at the 4th S\&ED in 2014. The CCWG aims to intensify this cooperative relationship by playing a role in facilitating enhanced policy dialogues among major policy makers and stakeholders in public and private sectors (US Department of State, 2014a). At the same time, the US and China signed eight new EcoPartnerships, including agreements on industrial boilers and forests, to strengthen the CCWG framework further (US Department of State, 2014c, 2014d). Both sides agreed

\footnotetext{
2 "The Memorandum of Cooperation between the National Development and Reform Commission of the People's Republic of China and the Environmental Protection Agency of the United States of America to Build Capacity to Address Climate Change" is its full title.

3 "The Protocol between the Department of Energy of the United States of America and the Ministry of Science and Technology and the National Energy Administration of the People's Republic of China for Cooperation on a Clean Energy Research Center" is its full title.
} 
to work together in order to reach a global agreement by the 21st Conference of Parties (COP) of the UNFCCC, scheduled to be held in Paris in December 2015 (Stern, 2014). The working group issued its first report to the 5th S\&ED in July 2013, with suggestions for launching new action plans for future cooperation. Later, in November 2014, before the close of the 22nd APEC economic leader's meeting, President Obama and President Xi released a Joint Announcement on Climate Change and Clean Energy, including their targets to cut 26 percent to 28 percent of GHG emissions from the 2005 levels by 2025 in the US, and to peak-out $\mathrm{CO}_{2}$ emissions by 2030 in China (US Department of State, 2015b, 2015c).

At the present time, the US and China's position on climate change and clean energy has been shaped based on their bilateral cooperation and through consecutive dialogues and communication. At the 7th S\&ED, held in June 2015, two public dialogues and a private joint session on climate change were organized, where two new CCS projects were announced as part of climate change cooperation undertaken by the CCWG (US Department of State, 2015a). These new projects include Ordos Basin Carbon Capture, Utilization and Storage (CCUS), the Enhanced Oil Recovery (EOR) project, and a Guangdong CCS project, all of which involve both public and private sectors. Moreover, over 50 outcomes of cooperation and many other energy efficiency and clean energy initiatives undertaken under the S\&ED were announced, including new CCUS projects, a new initiative on Green Ports and Vessels, the first-ever Climate-Smart/Low-Carbon Cities Summit, a new Race-to-Zero Emissions electric bus program, phase II of efficiency and emissions reduction from industrial boilers, and six new EcoPartnerships.

Substantially, the S\&ED has been providing abilateral platform for the two countries to negotiate over international agreements. With its CCWG, TYF, EcoPartnerships, and many other initiatives, the S\&ED has so far brought about both political-strategic and practical outcomes through dialogues and projects that national and sub-national public and numerous private actors participated in. Although international negotiations were in a deadlock for decades, the Sino-US bilateral cooperation became enhanced because energy-related technology transfers and information exchanges certainly served the interests of both the US and China. In other words, the objective to search for a strategic foundation in order to break through the stagnation in international negotiations, while meeting their practical purposes, remains crucial for the two countries to secure their national interests and to maintain influential positions in international negotiations.

As has been shown above, the Sino-US bilateral cooperation on climate change has increased to a significant level by initiating dialogues and various programs in recent years. However, certain concerns may persist. One concern that may be raised is the fact that the partnerships are not compulsory. In other words, they are not legally binding but simply based on initiatives, forums, dialogues, and voluntary projects/programs that could be negatively influenced by political confrontations or other exogenous factors. As Hodge and Greve (2007) suggest, PPPs have gained huge popularity in recent years but urgently need strengthened evaluation. The other potential concern is the difficulty of clarifying problems and measuring the effectiveness on each side as well as the partnership as a whole, due to the current lack of a comprehensive review and assessment mechanism.

\section{PPPs: The Ten-Year Framework (TYF) and EcoPartnerships}

The US-China EcoPartnerships program was established at the 2008 US-China SED, as part of the Presidential initiatives within the TYF. The TYF serves as a platform for the US and China to cooperate through projects in fields like clean air, clean water, energy security, efficiency, and so on. More specifically, both sides have signed over thirty EcoPartnerships hosted by public and private actors under the TYF to work 
on the goals and plans set by the S\&ED and MOU through practical projects and to meet their need to address mutual reciprocal demands (see Figure 1). The TYF and EcoPartnerships have since grown in numbers and expanded into a variety of diverse fields.

The EcoPartnerships program is administered by the US Department of State and China's National Development and Reform Commission (NDRC). In this program, each part establishes sub-national partnerships with a focus on seven areas, namely, "clean air", "clean water", "clean and efficient transportation", "clean, efficient and secure electricity", "energy efficiency", "Wetlands Conservation", and "Protected Areas/Nature Reserves". The program aims to benefit both sides in terms of policy output, knowledge and technological exchange, and practice management.

Actors that are currently involved in the EcoPartnerships range from public to private sectors including municipalities, such as counties and cities. Private actors include private firms, enterprises, academia, NGOs, NPOs, etc. The main purpose of the EcoPartnerships is to aim for the achievement of goals that benefit sub-national regions, society, sustainability, and economy in a multi-sectoral manner by cooperation between public and private actors (US Department of State, 2014b). Former Secretary of State Hillary Rodham Clinton stated at the signature ceremony of the EcoPartnerships that "Both of our countries have companies that are developing new and exciting technologies, universities that are doing groundbreaking research and local governments that have unique perspectives on the community environmental issues they face, which can have a global impact. This EcoPartnerships program was founded to bring these groups together to share best practices, foster innovation, and encourage sustainable development" (Clinton, 2010).

It is noteworthy that EcoPartnerships also aim to make a global impact. The SED, S\&ED, TYF, and the Partnerships were initially established under high-level political initiatives in order to lower the barrier of communication, to enhance mutual trust, and to build networks between the US and China. Political leaders on both sides likewise expected that the national (e.g., the S\&ED) and sub-national partnerships (e.g., the TYF, EcoPartnerships) would have international implications. Therefore, the outcomes of EcoPartnerships are expected to give constructive feedback and contribute to the TYF, bilateral cooperative relations, and even to influence global rule-making. As the EcoPartnerships secretariat stated, the mission of the program's initiative is "to elevate successful sub-national cooperation models to international prominence and by doing so, to spur broad replication by their peers in the US and China" (Clinton, 2011).

Up to present, the majority of EcoPartnerships are related to energy efficiency and clean air (see Table 3). This can be inferred from the urgent environmental issues, especially the serious air pollution, in major Chinese cities. $^{4}$ In particular, the US EPA has collaborated with its Chinese counterparts on climate change, pollutants limitation, air quality improvement, and many other topics under or outside the S\&ED. In addition to bilateral governmental cooperation, the USEPA provides technical support for data collection and management and multi-pollutant emission control, which involves academia, NGOs/NPOs, and local stakeholders.

\footnotetext{
${ }^{4}$ Interview with a research fellow at the Global Environmental Institute (GEI), January 18, 2016, Beijing.
} 
Table 3

An Overview of The US-China EcoPartnerships

\begin{tabular}{|c|c|c|c|c|}
\hline Focus areas & US Public & China Public & US Private & China Private \\
\hline Energy Efficiency & Municipal & $\begin{array}{l}\text { Municipal } \\
\text { State/Province } \\
\text { Gov./Ministry }\end{array}$ & $\begin{array}{l}\text { Academia } \\
\text { NGO/NPO } \\
\text { Enterprise }\end{array}$ & $\begin{array}{l}\text { Academia } \\
\text { NGO/NPO } \\
\text { Enterprise }\end{array}$ \\
\hline Clean Air & Municipal & $\begin{array}{l}\text { Municipal } \\
\text { State/Province } \\
\text { Gov./Ministry }\end{array}$ & $\begin{array}{l}\text { Academia } \\
\text { NGO/NPO } \\
\text { Enterprise } \\
\text { Foundation }\end{array}$ & $\begin{array}{l}\text { Academia } \\
\text { Enterprise } \\
\text { Foundation }\end{array}$ \\
\hline Clean Water & Municipal & Municipal & $\begin{array}{l}\text { Academia } \\
\text { NGO/NPO }\end{array}$ & $\begin{array}{l}\text { Academia } \\
\text { Enterprise }\end{array}$ \\
\hline Clean and Efficient Transportation & Municipal & $\begin{array}{l}\text { Municipal } \\
\text { State/Province } \\
\text { Gov./Ministry }\end{array}$ & $\begin{array}{l}\text { Academia } \\
\text { NGO/NPO } \\
\text { Enterprise } \\
\text { Foundation }\end{array}$ & $\begin{array}{l}\text { Academia } \\
\text { Enterprise } \\
\text { Foundation }\end{array}$ \\
\hline $\begin{array}{l}\text { Clean, Efficient, and Secure } \\
\text { Electricity }\end{array}$ & Municipal & \begin{tabular}{|l|} 
Municipal \\
State/Province
\end{tabular} & $\begin{array}{l}\text { Academia } \\
\text { Enterprise }\end{array}$ & $\begin{array}{l}\text { Academia } \\
\text { Enterprise }\end{array}$ \\
\hline Wetlands Conservation & Municipal & Municipal & $\begin{array}{l}\text { Academia } \\
\text { NGO/NPO }\end{array}$ & $\begin{array}{l}\text { Academia } \\
\text { NGO/NPO }\end{array}$ \\
\hline Protected Areas/Nature Reserves & N/A & N/A & $\begin{array}{l}\text { Academia } \\
\text { NGO/NPO }\end{array}$ & $\begin{array}{l}\text { Academia } \\
\text { NGO/NPO }\end{array}$ \\
\hline
\end{tabular}

Notes. Source: US-China EcoPartnerships. Available online at: https://ecopartnerships.lbl.gov/, last accessed June 19, 2015; Yu et al., 2015; Wang, 2015.

\section{The Implications of PPPs to the Sino-US Cooperation}

This section analyzes the implications of PPPs and the analytical framework of this study on the Sino-US cooperation as part of the SED and S\&ED. The analysis requires us to investigate whether the roles and approaches of PPPs-strategic, practical, and regulative roles with related instrumental, institutional, and normative approaches - have been introduced to the current Sino-US cooperation.

Firstly, one of the most important objectives of the Obama administration was to reach an alternative and practical agreement, while maintaining its satisfactory relations with China. Soon after his inauguration, President Obama explicitly emphasized the impact of climate change and indicated that it is an urgent issue that must be dealt with in a serious way. ${ }^{5}$ Furthermore, the US Secretary of State Hillary Clinton delivered a speech before attending the 5th East Asia Summit, in which she emphasized the common strategic interests between the US and China on global issues. She stated, "The two countries share the responsibility of constructing an obvious strategy in addressing climate change" (Clinton, 2010). The political will of top leaders has provided positive incentives for the US to cooperate with China regarding strategic purposes on energy, environment, and climate change. Considering its recent outcomes, the Sino-US cooperative relationship on climate change and energy contains a wide range of projects aimed at an ultimate goal, namely, to facilitate negotiations and reach international agreements that best suit both sides' interests. The US and Chinese leaders have emphasized the importance of working together in order to continue dialogues and forums with the primary aim of understanding each other better.

Obviously, another aim of the S\&ED relates to economic perspectives (e.g., industry, the market, employment). Some have argued that the Obama administration tends to expand its rights and interests by integrating standards and regulations with China on environmental technologies (Sasaki, 2011, p. 10). At the

\footnotetext{
${ }^{5}$ Steven Holland. (2008). Obama Says Climate Change a Matter of National Security. Reuters, December 9, 2008.
} 
same time, it is also an urgent task for China to solve domestic environmental degradation, such as air pollution and energy resource concerns, by introducing efficient technologies and systems while maintaining economic growth (Chinese State Council, 2007). Under the Sino-US S\&ED, as shown in Table 2, technological development, such as $\mathrm{CC}(\mathrm{U}) \mathrm{S}$, clean and renewable energy, electric vehicles, etc., covers a large proportion of the current environmental and energy cooperation. These works are not limited to strategic purposes and also indicate the practical function of US-China partnerships when it comes to their common goals, such as knowledge sharing, best practices, and benchmarking.

Thirdly, by agreeing that climate change should be tackled through a balanced approach that combines environmental technologies and opportunities for further economic growth, the US and China have come to consider energy efficiency and technological cooperation as crucial tasks to meet their common interests in promoting emissions reduction (Author, 2015). For instance, both sides try to integrate industrial and technological specifications and regulations while dealing with climate change and air pollution through measures such as $\mathrm{CC}(\mathrm{U}) \mathrm{S}$. The joint effort to reduce HFCs, a type of potent GHG with high global warming potential, is another example of co-regulation between both sides. As seen from the development, it is possible to infer the regulative role of PPPs as part of the current Sino-US cooperation.

The two countries can be regarded to benefit from instrumental and institutional approaches, such as opening up channels for both periodic and irregular bilateral dialogues, knowledge sharing, and to initiate climate-related programs and projects with the participation of public and private sectors. Moreover, the US and China have shown particularly positive positions and intentions in dealing with climate negotiations by establishing domestic regulations and international norms. As Rosenau mentioned in his book, "The real benefit of public-private policy partnerships may not be entirely evident as yet across the whole range of policy sectors, however, there appears to be some movement toward closer partnerships involving joint financing and responsibility in some areas" (Rosenau, 2000, p. 233). Although disagreements between the US and China have been considered a significant factor behind the long period of non-agreement under the UNFCCC, the outcomes (e.g., communiqué, MOUs, agreement on HFCs, etc.) of the Sino-US strategic dialogue, CCWG, TYF, and EcoPartnerships may have influenced their relatively harmonized relations on energy efficiency and climate change and the progressed international rule-making process that can be witnessed from recent negotiations.

\section{Conclusion}

Regarding the implementation of public-private partnerships, prior studies have mostly focused on the merit of service or infrastructure provision, cost-efficiency, quality performance, etc. However, there are few analyses that study the features according to political-strategic purposes, trust, and confidence-building, which can be inferred or empirically observed from the establishment of PPPs. Serving as a complement to prior studies, this study emphasizes the roles of PPPs, including their strategic perspective, by providing an analysis of the Sino-US cooperation regarding energy efficiency, environmental issues, and climate change. The Sino-US relations on climate change have likewise been mostly discussed with respect to the rivalry between these two major emitters and their reluctance to contribute to international cooperation. This study, in contrast, argues that cooperative partnerships have been established to a significant degree in recent years in order to promote bilateral cooperation on related issues.

In recent years, the US and China have begun to take the various adverse effects and risks of climate 
change seriously and to tackle the issue by facilitating mutual technological, academic, financial, and capacity building support through interaction between public and private actors. In particular, energy efficiency and environmental protection, including climate change, has been adopted as an adequate theme for constructing a mutually beneficial relationship. The two countries have enhanced more reciprocal relations in many topic areas through the process of initiating a range of projects on renewables, clean energy, electric vehicles and $\mathrm{CC}(\mathrm{U}) \mathrm{S}$, clean water, clean air, and so on. At the same time, public-private partnerships can be regarded as channels that enable the achievement of mutual sustainable development without causing significant confrontations or contradictions within each country. Through dialogues and implementation, cooperation on energy and environment-related issues has come to play an important part in enhancing US-China relations.

Undoubtedly, the motivations for the US and China to cooperate on energy and climate policies derive from their own interests. As the US and China have shifted their positions to cooperate by establishing partnerships, forums, and dialogues, it can be understood that both countries tended to treat energy and climate change as a strategic issue that can possibly affect their vital interests. That is, they became aware that national interests could be obtained by facilitating their collaboration on energy/climate-related clean technologies and policies. Against this background, on the one hand, China has achieved rapid economic growth while experiencing environmental degradation, such as soil, water, and air pollution. On the other hand, the economic problems of the US, such as unemployment and economic stagnation, need to be addressed. Under these circumstances, solutions related to energy efficiency and climate change provide opportunities for the two countries to cooperate on research, transfers, and the spread of environmental and energy-related technologies, which may relieve both countries of their excessive dependence on fossil fuels in the coming decades. To achieve these above-described goals, their cooperation demands the participation of both public and private actors.

Last but not least, it is important to continuously observe the implementation and influence of the Sino-USS\&ED, CCWG (with its numerous initiatives and projects), TYF, and EcoPartnerships from the perspective of PPPs. The first reason for this is the fact that Sino-US cooperation on energy efficiency and climate change was initially established for political purposes. A second reason, which is also a concern, may be the fact that extrinsic factors, such as security, political, and economic events, may negatively influence their cooperation. Therefore, the cooperation demands further assessment, review, and modification in order to improve and continue into the near future.

In addition to cooperate with China, the US has engaged with other primary GHG emitters, namely, India since 2014 and Brazil since 2015, to solve energy and climate change issues by applying similar approaches (US Department of State, 2015d). For instance, they have initiated strategic dialogues, launched working platforms such as the CCWG, enhanced collaboration among public and private actors, etc. In view of these developments, the public-private partnerships between the US and China deserve further study and assessment, not only because the two countries continue to be the biggest energy consumers and GHG emitters, but also because of the need to achieve a feasible framework for international cooperation and global governance.

\section{References}

Andonova, L. B. (2010). Public-private partnerships for the earth: Politics and patterns of Hybrid Authority in the multilateral system. Global Environmental Politics, 10(2), 25-53.

Beauregard, R. A. (1998). Public-private partnerships as Historical Chameleons: The case of the United States. In J. Pierre (Ed.), Partnerships in Urban Governance: European and American Experience (pp. 52-70). London: Palgrave Macmillan. 
Berkley, S. (2006). Ending an epidemic: The international AIDS Vaccine initiative pioneers a public-private partnership. Innovations, 1(1), 52-66.

Börzel, T. A., \& Risse, T. (2005). Public-private partnerships: Effective and legitimate tools of international governance? In E. Grand \& P. W. Louis (Eds.), Complex Sovereignty: Reconstituting Political Authority in the Twenty-First Century (pp. 195-216). Toronto: University of Toronto Press.

Bush, G. W. (2007). State of the Union Addresses of the American Presidents.

Carter, J. G. (2008). The structure and function of public-private partnerships for homeland security. Homeland Security Review, 2(3), 235-251.

Chinese State Council. (2007). China's national program against climate change. Chinese State Council.

Clinton, H. R. (2010). America's engagement in the Asia-Pacific. Retrieved September 8, 2012, from http://www.state.gov/secretary/rm/2010/10/150141.htm

Clinton, H. R. (2011). Remarks at US-China EcoPartnerships signing ceremony. U.S.: Department of State, Washington, D.C.

Committee on US-China Cooperation on Electricity from Renewable Resources, Policy and Global Affairs, National Research Council, Chinese Academy of Sciences and Chinese Academy of Engineering. (2010). The Power of Renewables: Opportunities and Challenges for China and the United States. Washington, D.C.: The National Academies Press.

Dewulf, G., Blanken, A., \& Bult-Spiering, M. (2012). Strategic issues in public-private partnerships (2nd ed.). Chichester: Wiley-Blackwell.

Fraser, R. (2002). Moral Hazard and risk management in agri-environmental policy. Journal of Agricultural Economics, 53(3), 475-487.

Haas, P. M. (1989). Do Regimes Matter? Epistemic communities and mediterranean pollution control. International Organization, 43(3), 377-403.

Han, G. Y., Hallding, K., Carson, M., Thai, H., \& Nilsson, M. (2009). China-US relations and domestic politics on the road to Copenhagen 1: Making a virtue of necessity. Stockholm Environment Institute.

Hodge, G., \& Greve, C. (2007). Public-private partnerships: An international performance review. Public Administration Review, 67(3), 545-558.

Intergovernmental Panel on Climate Change. (2013). Fifth Assessment Report (AR5), Summary for Policymakers (SPM). Intergovernmental Panel on Climate Change.

International Energy Agency. (2015). $\mathrm{CO}_{2}$ Emissions from Fuel Combustion. Paris: OECD/IEA.

Jasanoff, S., \& Marybeth, M. (2004). Earthly politics: Local and global in environmental governance. Cambridge: The MIT Press.

Kleinberger, D. S. (2012). Agency and partnership: Examples and explanations (4th ed.). New York: Wolters Kluwer Law \& Business.

Klitgaard, R. (2011). Designing and implementing a technology-driven public-private partnership (Innovations case discussion: India's Project Aadhaar). Innovations, 6(2), 67-72.

Kouwenhoven, V. (1993). The rise of the public private partnership: A model for the management of public-private cooperation. In J. Kooiman (Ed.), Modern Governance: New Government-Society Interactions (pp. 119-130). London: SAGE.

Linder, S. H., \& Rosenau, P. V. (2000). Mapping the Terrain of the public-private policy partnership. In P. V. Rosenau (Ed.), Public-private Partnerships (pp. 1-18). Cambridge: The MIT Press.

Lovrich, N. P. J. (2000). Policy partnering between the public and the not-for-profit private sectors: A key Policy Lever or a Dire warning of difficulty ahead? In P. V. Rosenau (Ed.), Public-private Partnerships (pp. 183-197). Cambridge, MA: MIT Press.

McGuire, M. (2000). Collaborative policy making and administration: The operational demands of local economic development. Economic Development Quarterly, 14(3), 276-291.

Peters, G. B. (1998). With a little help from our friends: Public-private partnership as institutions and instrument. In J. Pierre (Ed.), Partnerships in Urban Governance: European and American Experience (pp. 52-70). London: Palgrave Macmillan.

Porter, T. (2005). The private production of public goods: Private and public norms in global governance. In E. Grande \& P. W. Louis (Eds.), Complex Sovereignty: Reconstituting Political Authority in the Twenty-First Century (pp. 217-237). Toronto: University of Toronto Press.

Rabe, B. (2006). Race to the top: The expanding role of US state renewable portfolio standards. Sustainable Development Law \& Policy, 7(3), 10-17.

Sasaki, T. (2011). Features of the Obama Administration's economic strategy towards China. International Trade and Investment Quarterly, 83(10), 3-18. 
Savas, E. S. (2000). Privatization and public-private partnerships. New York: Chatham House.

Schaeffer, P. V., \& Loveridge, S. (2002). Toward an understanding of types of public-private cooperation. Public Performance \& Management Review, 26(2), 169-189.

Siemiatycki, M. (2006). Implications of private-public partnerships on the development of urban public transit infrastructure: The case of Vancouver, Canada. Journal of Planning Education and Research, 26(2), 137-151.

Stern, T. D. (2014). Remarks at the US-China strategic and economic dialogue. US Department of State.

Stevenson, M. (2014). Public-private partnering in natural resource extraction. Global Environmental Politics, 14(3), $139-145$.

Streck, C., \& Lee, D. (2016). Partnering for results: Public-private collaboration on deforestation-free supply chains. Prepared with support from cooperative agreement \#S-LMAQM-13-CA-1128 with US Department of State.

Tews, K., Busch, P. O., \& Jörgens, H. (2003). The diffusion of new environmental policy instruments. European Journal of Political Research, 42(4), 569-600.

United Nations Framework Convention on Climate Change. (2011). The Cancun Agreements: Outcome of the Work of the Ad Hoc Working Group on Long-term Cooperative Action under the Convention. FCCC/CP/2010/7/Add.1.

US Department of State. (2011). US-China strategic and economic dialogue 2011: Outcomes of the strategic track. US Department of State.

US Department of State. (2012). US-China ten year framework for energy and environment cooperation. US Department of State.

US Department of State. (2013a). The US-China EcoPartnerships program. US Department of State.

US Department of State. (2013b). Report of the US-China climate change working group to the strategic and economic dialogue. US Department of State.

US Department of State. (2014a). US-China climate change working group and ten-year framework for energy and environment cooperation meetings. US Department of State.

US Department of State. (2014b). Key achievements of US-China climate change cooperation under the strategic and economic dialogue. US Department of State.

US Department of State. (2014c). Six inducted into US-China ecopartnerships program. US Department of State.

US Department of State. (2014d). Joint US-China press statements at the conclusion of the strategic \& economic dialogue. US Department of State.

US Department of State. (2015a). The US-China ecopartnerships program. US Department of State.

US Department of State. (2015b). United States and china strengthen climate change cooperation. US Department of State.

US Department of State. (2015c). Fact Sheet on US-China climate cooperation. US Department of State.

US Department of State. (2015d). US-Brazil joint statement on climate change. US Department of State.

Walzer, N., \& Jacobs, B. D. (1998). Public-private partnerships for local economic development. Westport, CT: Praeger.

Wang, E. (2015). EcoPartnership on low-carbon and sustainable urban development. Journal of Renewable and Sustainable Energy, 7, 041501.

Westeren, K. I. (2000). Developing services in sparsely populated municipalities in Nordic countries. In P. V. Schaeffer \& S. Loveridge (Eds.), Small Town and Rural Economic Development: A Case Studies Approach (pp. 227-236). Westport, CT: Praeger.

Wynne, B. (1992). Uncertainty and environmental learning: Reconceiving science and policy in the preventive paradigm. Global Environmental Change, 2(2), 111-127.

Yale University and Columbia University. (2005). Environmental Sustainability Index: Benchmarking National Environmental Stewardship. Yale University and Columbia University.

Yu, Q. C., Roe, S. M., Xu, S. N., Williamson, S., Cui, N. Y., Jin, J. M., \& Peterson, T. D. (2015). China-US Cooperation on China's Subnational Low Carbon Planning Toolkit Development and Application. Journal of Renewable and Sustainable Energy, 7, 041501. 